\title{
Between the Natural and the Artificial: The Sublime Sexual Sensation of Car Crashes in J.G. Ballard's Crash
}

\author{
Green Letters
}

Regina Seiwald

School of English, Birmingham City University, Birmingham, United Kingdom

e-mail: Regina_Seiwald@hotmail.com

phone: +44 7542348400

Regina Seiwald has studied German Philology, English and American Studies, as well as General and Applied Linguistics at the University of Innsbruck, Austria. Studying in the School of English, Birmingham City University, she has recently passed her viva voce, in which she successfully defended her PhD on metafiction in contemporary British fiction. She is a PostDoctoral Fellow in the School of English at Birmingham City University and previously, Regina held a post as a teaching fellow in the German Department at the University of Birmingham. Her research interests are narratology, literary self-reflexiveness, postmodernism, game studies, and British fiction.

Word count: 6,487 words (exclusive of abstract, keywords, and bibliography)

\author{
Between the Natural and the Artificial: The Sublime Sexual Sensation \\ of Car Crashes in J.G. Ballard's Crash
}


At a time when technology progressively pushes back nature, the sexual act runs the risk of being denaturalised. The notion of the sublime, which I argue is how humans react to the machine as a surrogate for nature and as a sexual stimulus in Crash (1973), is therefore of central interest in this article. Ballard himself has described Crash as 'the first pornographic novel based on technology' $(1973,6)$. This engagement with a technologised sexuality is explored as a subjective narrative stance, which grants authenticity to the fictive alter ego, who can probe alternatives to an extra-textual reality. This narrative mode is notably potent in relation to the narrator's estimation of the merge between sexuality and technology in the form of car crashes uniting Eros and Thanatos. I therefore suggest that Crash can be read as an attempt to localise the natural and human in a world dictated by artificiality and technology.

Keywords: Ballard; Crash; sublime; inner space; autofiction; Eros and Thanatos

\section{Introduction}

When J.G. Ballard first sent Crash (1973) to a publisher, it was returned with a note saying '[t]his author is beyond psychiatric help. Do not publish!' (Svendsen 2005, 82). More than forty years later, the novel still sits uncomfortably with our notion of sexual relationships; what is a normal and what is an abnormal pronouncement of the carnal urge? However, this might well be the reaction Ballard sought to stimulate in his readers: to distort our notion of an assumed norm of sexuality that can only ever be artificial so that we enjoy 'feeling uncomfortable' (Barker 2003, 25). Ballard's mode of communicating this concern is through analysing the connection between sex and car crashes in many potential scenarios in order to fathom the possibilities of a sexual union between humans and the car. In this regard, Crash belongs to a kind of literature that Andrzej Gasiorek describes as 'exploring and perhaps coming to terms with the unprecedented scale of twentieth-century social and technological change, a way of grasping how and why human life had developed in the ways that it had' $(2005,9)$.

Crash explores the symphorophilic lust undergone by the narrator James Ballard by either staging or experiencing car crashes. ${ }^{1}$ Throughout the story, his fascination with Dr Robert Vaughan, whom he met shortly after being himself involved in a car crash close to London Airport, grows and even turns into nympholepsy forced by the

\footnotetext{
${ }^{1}$ Since author and narrator share the same name, Ballard the author is referred to as "Ballard" and Ballard the narrator as "James Ballard" hereafter.
} 
urge to perfect the sexual orgasm. Vaughan is surrounded by an odd group of followers, who are all former car crash victims and have their central life-event inscribed onto their bodies in form of scars resembling artworks. Their cicatrices symbolize a union of the 'body with the stylized contours of the instrument panel and windshield, [an] elegant posture with the violent conjunctions of colliding door panels and bulkheads' (Ballard 2014, 155). Vaughan and his group regularly set out to re-enact car crashes, which for them are 'a fertilizing rather than a destructive experience, a liberation of sexual and machine libido, mediating the sexuality of those who have died with an erotic intensity impossible in any other form' (Ballard 1990, chap. 12). In this act, the scars are seen as a new and elaborate mode of sexual sensation and in Crash, 'deformities became a potent metaphor for the excitements of a new violence' (Ballard 2014, 145), which James Ballard explores in his subsequent surreal sexual encounters with his wife Catherine, Dr Helen Remington (whose husband had died in the initial car crash), various other women, and Vaughan, too.

From a narrative perspective, Crash demonstrates what Martin Amis has described as essentially Ballardian, namely 'rejecting outer space in favour of "inner space" (2009, xii). The novel focuses on a narrator who bears the author's name in an autofictional mode and explores the complex interaction between "inner space" and the subjective appreciation of sublime technology in the outer realm of fictive text-internal reality. Autofiction combines autobiography and fiction and is defined by Frank Zipfel as 'the nominal identity between author and narrator in combination with genres that profess fictionality'2 $(2009,302)$. This similarity does not imply that author and narrator share the same identity; rather, the subjectivised narrative stance, which presents a fictionalised version of reality, allows Ballard's art to work through contradictions in the sense of challenging assumed social norms regarding sexuality in order to engage with sublime sensations of elements in reality. Old forms are thereby abandoned and new rules are constructed in the process of artistic production (Baxter 2008, 507-8). This has to do with autofiction being particularly suitable for transgressive depictions (Zipfel 2009, 309). "Transgressive" on the one hand denotes thematic aspects (in Crash the union of human sexuality and the machine in the car accident), but also the difference between non-fictional autobiographical and fictional writing. The division between the latter two cannot be maintained in autofiction, particularly since this

\footnotetext{
${ }^{2}$ My translation. '[...] Autofiktion durch die Namensidentität von Autor und Figur zusammen mit einer Fiktionalität behauptenden Gattungsbezeichnung gekennzeichnet ist[.]'
} 
narrative mode aligns with Paul de Man's claim 'that the distinction between fiction and autobiography is not an either/or polarity, but that it is undecidable' $(1979,921)$. In Crash, this subjective perception brought about by the autofictional narrative stance is notably evident in two fields: the veneration of technology and the technologised appreciation of nature. The fictive world is characterised by a disturbing absence of the natural and a predominance of (destructive) technology, yet the narrator presents his experience of his surrounding by assigning characteristics that were traditionally attributed to mighty powers in nature to technology. This allows him to engage with technology's sublimity in the confrontation with the boundaries of his own mind based on the life-threatening feeling evoked by car-crashes. The core of the novel is to be placed in the experience of 'an undefined sense of extreme danger, almost as if an accident was about to take place' (Ballard 2014, 37) linked with a strong urge for sexual sensation.

In this article, I shall discuss the potential of the autofictional narrative perspective to communicate sublime sensations in relation to technology, more specifically the car and car crashes. In a first step, I analyse the language used in Crash to impart the relationship between humanity and technology. Throughout the story, the narrator increasingly refers to the car with anthropomorphising terms, while simultaneously a surge of technical terms with reference to the human body becomes noticeable. Utilising an autofictional narrator allows for an analysis of the psychological effect of the technological sublime, notably to explore possible scenarios in a fictive setting as well as to probe the psychopathology of sexuality. This focalisation leads to insights into the narrator's psychological mechanisms, eminently his responses to a technologised sexuality. Sexual stimuli are such a personal concept and the engagement with them ensues from a highly subjectivised perspective, located in a realm that Ballard terms "inner space" in recourse to Sigmund Freud. With regard to this psychological mechanism in writing, Mark Thomas (2011, 334-5) sees an inherent connection between Ballard's "poly-perverse" and Freud's "polymorphous perversity," the latter to be found in the uncontrolled sexual urge of children. The insights gained from an engagement with language and the narrative perspective lead to the exploration of the idea that car accidents in Crash are situated between Eros and Thanatos, hence between the carnal urge and death. Vaughan in particular does not interpret death as a destructive force, but as the perfection of the orgasm in a union of the car and the body. 
These initial discussions form the framework for the second part of this article, namely the analysis of how the Romantic notion of the sublime, its legacy in Enlightenment and postmodernism are communicated in Crash in order to render the might of car crashes, particularly the impact they have on the narrator's sensory experience of his surrounding and how it influences his estimation of interhuman relationships. The autofictional narrative stance thereby again plays a central role: it allows the narrator to engage with the question of how the sexual act can be sensually orgasmic in an age marked by overstimulation dictated by man-made technology that has to be bigger, better, and smarter than what went before, which leads to the paradoxical situation that the technological sublime constantly has to outdo itself (Nye 1994, 27-28). The thesis is proposed that autofiction allows for probing the limits of the narrator's own (sexual) sensations in a fictive setting and for reflecting on a sublime experience brought about by technology. Since the notion of the sublime is always bound to the subject, I explore the relationship between the human and technology in the context of the highly subjectivised positions of inner space and autofiction. A transfer of characteristics normally associated with the might of nature onto the machine is precipitated, hence damaging the basic underpinning of society, i.e. humanity's relationship with the natural world. These two sections allow me to determine how Crash localises the subject and its sexuality in a world dictated by the machine in the concluding part of my article.

\section{Language and the Attempt to Communicate Subjective Experience}

Ballard's language utilised to describe car crashes evokes concepts traditionally related to notions of the Romantic sublime - a might that cannot be described, but only experienced. The Romantic sublime differs from Longinus's, who defined this concept as a method of rhetoric to verbally describe something elevated or great. It also differs from Edmund Burke's concept of the sublime proposed in the eighteenth century as the mutual exclusion of the sublime and the beautiful. For Burke, it is essential that the one perceiving sublimity is removed from it, hence knows himself or herself to be in safety, which allows the experience of the sublime as pleasurable despite its terror (Beardsley 1973, 27). Furthermore, as Matthew W. Binney argues, 'Burke's aesthetic component of the sublime begins with the senses and ends with the subject's emotional response to sense experience' $(2013,647)$. Burke's sublime therefore differs from the Romantic sublime, which is characterised by the subject's return to reason and the realisation of 
its own greatness in relation to the sublime object. Contrarily, Burke's sublime is grounded in emotion, whilst the Kantian sublime is defined by reason. It is also rooted in observation rather than analysis.

Ballard's use of language is not only closer to the Romantic sublime because of the implied inexpressibility of the sublime despite the attempt to analyse the sublimity of car crashes through language, but also because of the relationship between the spectator and the sublime object: Romanticism's relationship with nature is mirrored in the contemporary's relationship with technology; humans are fascinated by technology due to its incomprehensible might. This technology is a "hyperobject" in Timothy Morton's sense - entities that 'are so massive that humans can think and compute them, but not perceive them directly' $(2014,489)$. These hyperobjects are approached by man through an attempt to describe them; one such mode is art (and Morton mentions H.G. Wells's The War of the Worlds as a potent communicator of the age of the Anthropocene). Ecocriticism as an underlying concept in literature can therefore communicate the relationship between natural hyperobjects and man.

While nature and art are combined in ecocriticism, Ballard includes technology in this discourse. Humanity in its response to the world is still central to this debate, yet the formerly predominant role of nature is replaced by technology in order to indicate nature's disturbing absence in Crash. That is to say, the role of nature in Crash is defined by its replacement with technology. In this context, Jim Clarke has suggested that it is essential for climate change 'to conceive of its beautiful but terrible sublimity in the face of species death' $(2013,20)$. Crash ascribes a divine status to technology since it possesses an unquestioned, yet unjustified role in its ability to "solve problems" caused by nature, such as floods and storms. Thus, by depicting the sublimity of the machine, Ballard reflects today's debate about technology both as the ravager and saviour of humanity in the age of the Anthropocene. Ballard utilises language traditionally used for car parts or technology to refer to the human body and nature. It is helpful to understand the relationship between technology (and man-made objects in the broader sense) and nature as well as how we refer to both concepts by means of language in terms of Patrick Curry's distinction between anthropocentrism, 'a worldview that locates all agency and value in humanity alone' (2008, 53), and ecocentrism, 'which locates value and/or agency within nature as such, including [...] humanity' (54). Technology and nature should thus not be referred to by terms of difference, but rather in terms of (dis)similarity. 
The intrinsic link between the machine and the human being ascribed by James Ballard is strongly reflected in the language used to describe both. While cars are mostly referred to by anthropomorphised terms, people (and notably women) are frequently objectified due to the technological terms utilised when characterising them. Crash attributes an almost divine status to cars, which are seen as artworks rather than machines. The man-made creations of the urban space are thereby positioned as something beautiful, almost soothing: 'Along the elegant motion sculpture of the concrete highway the coloured carapaces of the thousands of cars moved like the welcoming centaurs of some Arcadian land' (Ballard 2014, 137). For James Ballard, the car is seen as the beacon of a new paradise that unifies the natural and the machine. In order to fully reach this union, an additional process has to be initiated as well: to merge the human body into the car. One way to achieve this is to refer to the human body with terminology akin to that traditionally utilised when describing cars, such as when the narrator speaks of the 'taxi's body frame' (Ballard 2014, 127) or the 'stainless-steel body-sill mouldings' (140). The sexual arousal constituted by the body is thereby always also linked to its mechanisation. James Ballard seems to be fascinated by his epiphany regarding the sexual stimulation triggered by the car, most notably when he describes that his eyes were 'moving from the dented curvatures of the bonnet and fenders to the cleft of Vaughan's buttocks. The destruction of this motorcar and its occupants seemed, in turn, to sanction the sexual penetration of Vaughan's body' (Ballard 2014, 104). The body and the car become one in 'unions of torn genitalia and sections of car and instrument panel' (109).

Language attempts to explain the vastness of this overwhelming unity between sexuality and technology, but this cannot but result in an incomplete depiction. Rowan Wilken argues that in order to establish a 'relation between imagination and intellectual ideas of reason' $(2012,198)$, metaphors are utilised to express and make sense of this prevailing chaos. Christine Brooke-Rose $(1958,206)$ contends that verbal or adjectival metaphors are utilised as reifications when people are treated as objects, but in literature that draws extensively on technology, this concept is reversed by personifying objects. Machines are frequently furnished with humanoid features, most notably sexuality. In the moment of the car crash, the machine penetrates the human body and demonstrates its power for destruction, thereby reversing the creational potential of sexuality, as when James Ballard admires the conjunctions between elbow and chromium window-sill, vulva and instrument binnacle' (Ballard 2014, 85). The car and the body become one, 
while the machine itself, which operates in ways unaccountable to most humans, functions as a metaphor for the sublime. Enlightenment nature has thus been replaced by man-made technology, but the effect is still the same: the artist tries, in JeanFrançois Lyotard's words, to put 'forward the unpresentable in presentation itself' $(1984,81)$.

\section{Sublime Technology: The Age of the Autogeddon}

\section{Man and the Machine}

In Crash, the car is attributed with almost divine characteristics, yet it is still mostly the human being who has control over it - he, too, can penetrate it and frequently does so: 'What most disturbed me about Vaughan was the strange stance of his thighs and hips, almost as if he were trying to force his genitals through the instrument panel of the car' (Ballard 2014, 70). This penetration leads to an unprecedented union between man and the machine, 'an amalgam of rectal mucus and engine coolant' (Ballard 2014, 121), which results in the ultimate sexual fulfilment. Yet, while the male characters in Crash use this union as a positive force, it is mainly destructive for women. Their wounds form new potentials for sexual penetration, as has been described by Jean Baudrillard:

\footnotetext{
Every gash mark, every bruise, every scar left on the body is an artificial invagination [...]. And these few natural orifices which we are accustomed to associate with sex and sexual activities are nothing in comparison to all these potential wounds, to all these artificial orifices (but why "artificial"?), to all these openings through which the body turns itself inside out and, like certain topologies, no longer possesses an inside or an outside (1991, 315-16).
}

This fascination with wounds as places for sexual sensation and the subsequent degradation of women as objects used for pleasure is most explicit with regard to Gabrielle, a young woman whose body has been severely damaged in a car accident, but whose wounds James Ballard uses to satisfy his sexual needs: 'Each of her deformities became a potent metaphor for the excitements of a new violence' (Ballard 2014, 145) while he is having his 'first orgasm within the deep wound of her thigh' (148). Apart from Catherine and Helen, women remain powerless (and often also nameless) in Crash, while the narrator fantasises about 'the breasts of teenage girls deformed by instrument binnacles, the partial mammoplastics of elderly housewives carried out by 
the chromium louvres of windshield assemblies, nipples sectioned by manufacturers' dashboard medallions' (Ballard 2014, 108). What this implies is that while the anthropomorphisation of the car, the objectification of the human, and the machinic/artificial property of sex indeed have a power-granting effect for the male characters, they are seen as destructive forces for women, who symbolise the natural.

Despite the disturbing predominance of technology and man-made objects in Crash, the narrative also makes one of the most natural acts a central concern: sex. Yet, this sexual act is not depicted as a sensual experience, but rather as an urge created and dictated by the machine. In Crash, sex and technology cannot be separated, as Brian Baker states: 'the car-crash and the moment of orgasm are literally overlaid to explore or propound a new kind of sexuality, one determined by the conditions of contemporary, late capitalist life' $(2000,84)$. This is particularly evident in instances where the narrator makes the machine an integral part of the sexual act, 'fusing together [...] sexuality and the hard technology of the automobile' (Ballard 2014, 156). Sex as an act for potential creation is intrinsically linked with car crashes as potential (in Crash frequently even certain and desirable) death, thus placing the subject in the area of conflict between Eros, the strong urge for 'a desire to go beyond the boundaries of the self' (Baker 2000, 86), and Thanatos, the death-drive (Cranwell 2010, 272-73). Yet, as Baker argues in recourse to Baudrillard, the relationship between Eros and Thanatos is complex because 'the representation of the car-crash' does not function 'as a technological extension of the death-drive but as a site of a different sexuality' $(2000,88)$. Baker thus suggests that the car crash is not a striving towards Thanatos in Crash, but actually the most sublime realisation of Eros. Vaughan in particular symbolises this complex interaction between Eros and Thanatos by 'visualiz[ing] himself in a sexual act with [Elizabeth Taylor], dying together in some complex car-crash' (Ballard 2014, 141) and William S. Burroughs notes that the narrative explicitly advocates that '[a]n auto crash can be more sexually stimulating than a pornographic picture' (1990, preface). The fatal car crash is thereby seen as the ultimate orgasm that is linked to the stylisation of a brutish violence, creating a ménage-à-trois between the car, sexuality, and death. As Sam Francis contends,

Crash's surreal central image of the crash-death as orgasm argues the inextricable intertwining of the erotic and deathly instincts, an intertwining Hal Foster and 
others have argued is implicit in Freudian theory and which is enshrined in the popular imagination through the idea of the orgasm as petit mort $(2008,152)$.

Nature as located in the sexual act is thus not absolutely absent in Crash, but its dependence on technology is depicted in a distorted anthropomorphisation of cars. Vaughan becomes the obscured product of this pull between Eros and Thanatos, one 'who could never really die in a car-crash, but would in some way be re-born through those twisted grilles and cascading windshield glass' (Ballard 2014, 172). He is the product of the sexual union between the human and the car.

The world in which James Ballard moves is thus dictated by technology, cars, and man-made constructions, such as airports, motorways, and scrap yards. His response to this technology resembles a sublime veneration by presenting it as an anthropomorphised object that reaches beyond the comparable. The experience of technological power is something perceptible that transgresses notions of beauty because of its unutterable might, but also something that arouses pleasant terror. The feelings evoked in the subject connect it to sensations of elusiveness and immeasurability - in Crash's case in form of an extensively felt lust caused by the immanent danger of death when ' $[\mathrm{t}]$ he collision of our two cars, and the death of her husband, has become the key to a new sexuality' (Ballard 2014, 96) between Remington and James Ballard. Although this fascination is directed towards technology, these reactions have to be interpreted in relation to the one perceiving it. The reason for this is that in a Kantian framework, 'the important stage in the experience of the sublime occurs not during one's awe or terror at the immensity of nature, but rather in the final return to reason which takes place once the imagination has faced its limits' (Ellison 2001, 14). What holds true for nature holds true for technology in the context of Crash. Shortly after his car crash with Remington, James Ballard observes that he "was aware that the interlocked radiator grilles of our cars formed the model of an inescapable and perverse union between us' (Ballard 2014, 15). He realises the implications of this car crash in a return to reason, yet one that is determined by parameters established by him: his notion of a normal sexuality has shifted towards the perverse after experiencing the car crash. Hence, not the life-threatening feeling evoked by the sight of the crash and its victim, but the confrontation with the boundaries of one's own mind causes a sublime feeling. 


\section{Sublime Sensations: The Machine as a Sexual Stimulus}

While Longinus defined the sublime as an adjective used in rhetoric to refer to something generating veneration and awe, the Romantic sublime, which underpins Crash, faces the paradox of being itself unutterable: it 'produces sublimity from within itself, and is, therefore, more than a commentary upon sublime sensation' (de Bolla 1989, 35). This is what the sublime shares with Crash; the novel aims at depicting the sexually stylised aspect of car crashes in a world that has accepted the automobile as one of its most inherent elements despite its destructive powers. Even more so, Andrea Juno and V. Vale write, 'the Ballardian landscapes describe empty swimming pools, concrete freeways, deserted resorts, decaying cities and abandoned Space launching pads, peopled by media stars such as Charles Manson, Jacqueline Kennedy, Marilyn Monroe and Ronald Reagan' (1990, introduction). Crash's world is thus quintessentially artificial and stylised. The hyperobjects presented in the text are the result of the 'irreducible gap between phenomenon and thing' (Morton 2014, 491). Ballard shows the extreme effects this gap brings about by characterising the relationship between technology and nature as one of a perverse dominance of the former over the latter; the sublime becomes re-phrased as a form of cosmic horror. Nature is defamiliarised and the only presence of the natural apart from the sexual act is located in '[t]he deserted reservoirs [that] lay around us in the sunlight, an invisible marine world' (Ballard 2014, 97). James Ballard's universe is dominated by chromium, concrete, and plastic, filtered through rear-view mirrors and glass panels.

Like Ballard's union of the natural (sex) and the man-made (the car), the sublime discourse becomes an integral part of what it actually discusses. Even in ugliness, the sublime determines itself by seemingly bursting every notion of form and urging the spectator to imagine infinity. Crash engages with this idea by defining crashed cars as artworks, for example when referring to the scrapyard as a 'museum of wrecks' (Ballard 2014, 51), which Remington reviews 'like an intelligent gallery visitor' (53). Ballard here seems to put the argument into practice that sublime objects need not be beautiful, but must exert a strong allure on the onlooker's mind. The feeling evoked in the narrator upon seeing his wrecked car, this 'instrument of a perverse technology' (Ballard 2014, 55), is of a strong longing for a sexual union between him and Remington in form of a 'new choreography of violence and collision' (67).

The power and might of Kantian sublimity shows itself to the spectator in secure distance from it in order to "exhibit our faculty of resistance as insignificantly small in 
comparison with their might' (Kant 2012, 75). The commotion released by their first sight is mixed with fear, but since the onlooker is not directly affected by the jeopardy emanating from the object because they are at a secure distance, the powers of nature or technology in relation to themselves can be fully explored, triggering an awareness of the potency of mind and reason, thus raising the human from an inferior position. James Ballard functions as such a transcendental subject in Crash, who constructs the very nature he experiences as sublime. He drives the sex act as he drives the machine: 'I opened the window and inserted more coins into the cash meter. As the water jetted on to the streaming panes Vaughan and my wife began to make love again' (Ballard 2014, 133-34). Automaton-like, the agents involved in this sex act are only enlivened once he has paid for their function. This has the effect that at the moment he realises the might of the machine, he simultaneously realises his own superiority. The absence of pleasure felt by the initial sight of an object triggering a sublime feeling, such as the superior powers of the machine or, even more so, car crashes, is replaced by pleasure as soon as the subject's own grandeur is identified, which awakens it from its lack of power. Yet, the narrator constantly tests the boundaries of this sublime sensation: He does not let his readers witness his reactions to car crashes at a safe distance, but almost urges us to explore this feeling directly by taking part in them, by becoming a victim of the machine.

Whereas Kant advocates that the sublime in art is derived from the sublime in nature, Theodor W. Adorno sees both in mutual interdependence. In the context of the aftermath of the Second World War, Adorno discusses the modern sublime in conjunction with his aesthetics of the "not-identical," which cannot but be grounded in negativity: 'The more deeply artworks immerse themselves in the idea of harmony, of the appearing essence, the less they can be satisfied with that idea' $(1997,110)$. The sublime in art does not aim at reconciliation because this would rob it of the potential of evoking awe in the spectator. On the contrary, art needs to highlight insurmountable contradictions, yet paradoxically they become hidden behind words as soon as they are expressed in language. Harmony, then, destructs this non-identity by means of convergence of the unrepresentable into a presented object. James Ballard's sexuality is so radically new that its sensual experience cannot be depicted in language. Even more so, it seems that he himself initially cannot relate to this sensation felt during and after his car crash: 
Two firemen cut the door from its hinges. Dropping it into the road, they peered down at me like the assistants of a gored bullfighter. Even their smallest movements seemed to be formalized, hands reaching towards me in a series of coded gestures. If one of them had unbuttoned his coarse serge trousers to reveal his genitalia, and pressed his penis into the bloody crotch of my armpit, even this bizarre act would have been acceptable in terms of the stylization of violence and rescue (Ballard 2014, 14).

James Ballard describes his post-accident experience through imagery evoking Ernest Hemingway's The Sun Also Rises (1926), whose central themes are bullfighting as a symbol of male sexuality and sexual acratia resulting from the physical and psychological injuries stemming from the experience of war. The autofictional mode of narration seems particularly relevant here because it allows the reader to witness highly subjective reactions to an otherwise censored topic: sexual potency in the face of violence. James Ballard thereby communicates 'purely subjective projections rather than genuine social diagnoses' (Gasiorek 2005, 152), yet Baudrillard emphasises that in Crash, '[d] eath, wounds, mutilations are no longer metaphors of castration' (1991, 315). They are sexual stimuli. In The Atrocity Exhibition, Ballard quotes pseudo-research to prove that ' $[\mathrm{t}]$ ests on a wide range of subjects indicate that the automobile, and in particular the automobile crash, provides a focus for the conceptualizing of a wide range of impulses involving the elements of psychopathology, sexuality and self-sacrifice' (Ballard 1990, chap. 12). Violence as a sexual stimulus appears to be particularly important for Vaughan, who sees crash wounds as 'the keys to a new sexuality born from a perverse technology' (Ballard 2014,6). The union between sex as the natural and the car crash as the stylised art of (near-)death therein explores Adorno's union between nature and art as the generators of the sublime.

Adorno's sublime hence reflects the modern aim at building coherence in a fragmented and shattered world; Lyotard's postmodern sublime, on the other hand, 'celebrates avant-garde art and its continuous rule-breaking, which pushes the viewer toward the limits of perception and the intuition of the unrepresentable' (Nye 1994, xx). The subject realises that an adequate presentation of the unrepresentable is impossible, but the constant urge to try and achieve this perfect presentation demands from the artist new and inventive forms. Ballard tries to communicate this inexpressible sublime technology and in Crash he does so by staging a union between the car and the human 
being in a relationship that cannot be defined. Body and car parts seem to merge, as when James Ballard 'presse[s] the head of [his] penis against the lower rim of the steering wheel' (Ballard 2014, 57); bodily and machine fluids become one in 'a blend of semen and engine coolant' (81). Baudrillard has rightly noted that 'all the erotic vocabulary is technical: not ass, prick, or cunt, but anus, rectum, penis, vulva. No slang, no intimacy in the sexual violence, only functional language' (1991, 316). These descriptions often sit uncomfortably with the readers' idea of a sensual sexuality that is based on feeling and difficult to express in language. However, since art and the notion of the sublime since Romanticism share that there is always one part that cannot be represented, art can express this vestige in every shape possible. Within such an approach, old forms and regulations are abandoned and new rules are constructed in the process of artistic production.

Lyotard's theory thus stresses the boundaries of narrative representation at which the sublime is to be located, while the Kantian sublime has worked with the cognitive boundaries of human reason: 'For Kant, the sublime is the natural, sensible, and conceptual world exceeded; for Lyotard, it is cultural, man-made technologies and discourses gone wild, beyond rule, exceeding what is presentable' (Engström 1993, 197). Ballard's sublime is thus closer to Lyotard's concept as the only natural elements we have in Crash's fictive world are sexuality and the (man-made) reservoirs. While this world might stimulate an eerie and surreal feeling in the reader, the new sexual possibilities presented therein are embraced by the narrator:

As obsessed with his hard body as he [Vaughan] himself was with the bodies of automobiles, I found myself locked into a system of beckoning violence and excitement, made up of the motorway and traffic jams, the cars we stole and Vaughan's discharging sexuality (Ballard 2014, 142).

James Ballard seems not to fight this situation he is in, but rather deeper and deeper indulges in the perverse lust that he can explore. Although Lyotard abolishes Kant's transcendental subject as the key to sublime experience, he moves the impact the subject has on the construction of this 'unrepresentable in presentation' (Lyotard 1984, 81) to postmodern experimental narrative structures. This also means that just like sublime nature, sublime art runs the risk of being normalised; as soon as the unrepresentable is represented, it establishes a paradigm on which to draw in subsequent 
depictions (Engström 1993, 194). However, the brisance of Crash's tendency to break with moral taboos appears to be still valid today. Postmodern writers are able to present constructions that trigger a sublime feeling in the reader 'at precisely the point where the proliferating categories break down, giving way to an all but irrepressible heteroglossia' (Tabbi 1995, 16).

Crash hence initially appears to be closer to Adorno and Lyotard's sublime than to earlier formulations. However, in the context of postmodern technological developments, Kant's sublime provides an apt framework for the analysis of cars. Undoubtedly, 'the similarity between our engagement with nature and the engagements we have with various forms of technology' (Wilken 2012, 192) allows us to apply Kantian insights to the depiction of cars. The aesthetics of accidents in Crash and their simultaneous veneration as an integral part of our society within and outside the fictive world seem to transcend our notions of reason due to the proposed 'marriage of violence and desire' (Ballard 2014, 128). Yet, the realisation of this new technological sublime also leads to the transgression of our mental capacities because " $[\mathrm{t}]$ he verbal construction $[\ldots]$ is never adequate to the technological object; the mind that would conceive itself as energy and force is dwarfed in relation to technological force' (Tabbi 1995, 17); and it 'is in this realm of excess signification at the boundaries of discourse, the point at which meaning is overwhelmed and entropy threatens to take over, that the technological sublime [...] begins to function in literature' (17).

The advancement of the technological sublime can be linked to Fredric Jameson's argument that, in Gillian B. Pierce's words, the natural 'has been destroyed by the forces of late capitalism' $(2012,3)$. Sublimity always also expresses the relation between the decentred subject and the technology surrounding it and since this technology cannot be described holistically or grasped in all its elements, it unavoidably leads to alienation. The resulting vacuousness is mirrored in fragmented, chaotic language and the cognitive dissonance of the subject. This dichotomy between pleasure and absence of pleasure, order and chaos, norm and deviation is intrinsically linked to autofiction in its exploration of the inner space. As argued earlier, Ballard's narrative stance is marked by a large degree of subjectivised descriptions of the fictive world and the narrator's reactions to his surroundings. On the one hand, this is due to the author's fascination with the concept of inner space, and on the other hand it is owed to employing an autofictional perspective. In the "Crash!" chapter published in The Atrocity Exhibition, Ballard comments that 
Freud's classic distinction between the manifest and latent content of the inner world of the psyche now has to be applied to the outer world of reality. A dominant element in this reality is technology and its instrument, the machine (1990, chap. 12).

It therefore seems appropriate not to depict the status of the machine in society from an objective position, but from within the subject who experiences and explores it. In this regard, the investigation of the inner space in a fictional narrative strongly resembles the stream of consciousness, yet Ballard adds an autofictional narrative mode in order to grant his account more authority, more authenticity. His James Ballard serves as a fictive alter ego that allows him to explore scenarios beyond the socially acceptable, such as penetrating the wounds of car crash victims, sexually abusing underage prostitutes, or willingly causing accidents, whereby others are injured and killed. We can trace the narrator's thoughts when he is '[r]eading an imaginary biography into the history of the skin' (Ballard 2014, 32) and even more so when he is 'convinced that Vaughan was a projection of my own fantasies and obsessions' (181). The reason for this is that unlike the autobiography, which can be characterised as a process of selffinding, autofiction also denotes self-invention (Zipfel 2009, 307). That is to say, while this narrative mode is concerned with the author's self, this self is overtly fictionalised and transposed into a fictive realm. Only this allows for an engagement with improbable or impossible situations from an authenticated, subjectivised position.

\section{Conclusion}

As this analysis of the technological sublime has shown, the natural is not completely absent in Crash, but a dominance of the de-naturalised is constituted, which is unavoidable due to the dominance of the machine. The natural cannot survive in its original form, but has to adapt to the new technological Ballardian universe of the 'autogeddon' (Ballard 2014, 37). Crash internalises today's debate about technology both as the ravager and the saviour of humanity in the age of the Anthropocene. The rendering of the inner space from an autofictional narrative stance is a potent mode to engage with the psychological effects of the technological sublime and in particular with the de-sensualisation of the sexual act. The latter is a prominent topic in Crash, most notably uttered in James Ballard's observation after having intercourse with 
Catherine that ' $[\mathrm{b}] \mathrm{y}$ some paradox, the sex act between us had been devoid of all sexuality' (Ballard 2014, 175). What is left, then, of the sexual act is for the reader to infer, but what is certain is an inherent lack of feeling. The reason for this can be found in the desensitizing of humans in the age of the machine. As Dennis A. Foster argues,

Ballard sees an affective flaw in the heart of the late capitalist machine age: [...] feeling, when it is still possible to evoke it, is tied to a perversion in entertainment, advertising, and technology, a displacement of human relationships into consumer culture and machine image $(1993,519)$.

Yet, while this lack of feeling initially results in alienation on the side of the reader, James Ballard seems to fully embrace it. His ideal sex appears not to be sensual, but marked by a constant search for new possibilities of how to penetrate the body in order to reach satisfaction.

This unique combination of autofiction and inner space further has the effect that ' $[\mathrm{t}]$ he line between inner and outer landscapes is breaking down. Earthquakes can result from seismic upheavals within the human mind' (Burroughs 1990, preface). And these tremors are what fascinate James Ballard because they do not follow an artificial social norm, but are defined by a deviation from it to the effect that in Crash, '[i]t is clear enough from the outset that conventional bourgeois sexual morality has long since been abandoned in James Ballard's personal world' (Thomas 2011, 354). His world is one in which technology, sexuality, and lust become the new mode of personal experience to the effect that all three merge and become the core of the alienated human in a reality dictated by the unnatural.

\section{References}

Adorno, Theodor W. 1997. Aesthetic Theory. Edited by Gretel Adorno and Rolf Tiedemann. Translated by Robert Hullot-Kentor. London: Athlone. 
Amis, Martin. 2009. "Introduction.” In The Complete Stories of J.G. Ballard. New York: W.W. Norton \& Company.

Baker, Brian. “The Resurrection of Desire: J.G. Ballard's Crash as a Transgressive Text." Foundation 80 (2000): 84-96. ISSN: 0306-4964.

Ballard, J.G. 1973. Crash. London: Vintage.

Ballard, J.G. 2014. Crash. London: Fourth Estate.

Ballard, J.G. 1990. "Crash!” Chap. 12 in The Atrocity Exhibition, edited by V. Vale and Andrea Juno. San Francisco: Re/Search.

Barker, Martin. 2003. "Crash, Theatre Audiences, and the Idea of 'Liveness."” Studies in Theatre and Performance 23 (1): 21-39. doi: 10.1386/stap.23.1.21/0.

Baxter, Jeannette. 2008. "Radical Surrealism: Rereading Photography and History in J.G. Ballard's Crash." Textual Practice 22 (3): 507-528. doi: 10.1080/09502360802264673.

Baudrillard, Jean. 1991. "Ballard's Crash.” Science Fiction Studies 18 (3): 313-320. URL: http://www.jstor.org/stable/4240083.

Beardsley, Monroe C. 1972. "History of Aesthetics.” In Encyclopedia of Philosophy, edited by Paul Edwards. Volume 1 of 8 . New York: Macmillan.

Binney, Matthew W. "Edmund Burke's Sublime: Cosmopolitan Aesthetic." SEL Studies in English Literature 1500-1900 53.3 (2013): 643-66. doi: 10.1353/sel.2013.0023.

de Bolla, Peter. 1989. The Discourse of the Sublime: Readings in History, Aesthetics and the Subject. Oxford: Basil Blackwell.

Brooke-Rose, Christine. 1958. A Grammar of Metaphor. London: Secker \& Warburg. Burroughs, William S. 1990. "Preface.” In The Atrocity Exhibition, edited by V. Vale and Andrea Juno. San Francisco: Re/Search.

Clarke, Jim. 2013. "Reading Climate Change in J. G. Ballard.” Critical Survey 25 (2): 7-21. doi: 10.3167/cs.2013.250202.

Cranwell, Caresse. 2010. "Embracing Thanatos-in-Eros: Evolutionary Ecology and Panentheism."Sophia 49: 271-283. doi: 10.1007/s11841-010-0177-5. 
Curry, Patrick. "Nature Post-Nature.” New Formations 64 (2008): 51-64. ISSN: 09502378.

Ellison, David. 2001. Ethics and Aesthetics in European Modernist Literature: From the Sublime to the Uncanny. Cambridge: Cambridge University Press.

Engström, Timothy H. 1993. "The Postmodern Sublime?: Philosophical Rehabilitations and Pragmatic Evasions.” Boundary 220 (2): 190-204. doi: 10.2307/303363.

Foster, Dennis A. 1993. “J. G. Ballard's Empire of the Senses: Perversion and the Failure of Authority." PMLA 108 (3): 519-532. doi: 10.2307/462619.

Francis, Sam. 2008. ““Moral Pornography' and 'Total Imagination': The Pornographic in J. G. Ballard's Crash.” English 57 (218): 146-168. doi: 10.1093/english/efn011.

Gasiorek, Andrzej. 2005. JG Ballard. Manchester: Manchester University Press.

Juno, Andrea, and V. Vale. 1990. “Introduction.” In The Atrocity Exhibition, edited by V. Vale and Andrea Juno. San Francisco: Re/Search.

Kant, Immanuel. 2012. Critique of Judgment. Translated by J.H. Bernard. New York: Dover.

Lyotard, Jean-François. 1984. The Postmodern Condition: A Report on Knowledge. Translated by Geoff Bennington and Brian Massumi. Manchester: Manchester University Press.

de Man, Paul. 1979. “Autobiography as De-Facement.” Modern Language Notes 94: 919-930. doi: 10.2307/2906560.

Morton, Timothy. "Victorian Hyperobjects." Nineteenth-Century Contexts 36.5 (2014): 489-500. doi:10.1080/08905495.2014.974940.

Nye, David E. 1994. American Technological Sublime. Cambridge: MIT Press.

Pierce, Gillian B. 2012. "The Sublime Today: Aesthetics and the Postmodern Mediascape." In The Sublime Today: Contemporary Readings in the Aesthetic, edited by Gillian B. Pierce, 1-12. Newcastle upon Tyne: Cambridge Scholars.

Svendsen, Lars. 2005. A Philosophy of Boredom. Translated by John Irons. London: Reaktion Books. 
Tabbi, Joseph. 1995. Postmodern Sublime: Technology and American Writing From Mailer to Cyberpunk. Ithaca: Cornell University Press.

Thomas, Mark. 2011. "The Rules of Autogeddon: Sex, Death and Law in JG Ballard's Crash." Griffith Law Review 20 (2): 333-361. doi: 10.1080/10383441.2011.10854701.

Wilken, Rowan. 2012. “'Unthinkable Complexity': The Internet and the Mathematical Sublime." In The Sublime Today: Contemporary Readings in the Aesthetic, edited by Gillian B. Pierce, 191-212. Newcastle upon Tyne: Cambridge Scholars.

Zipfel, Frank. 2009. “Autofiktion: Zwischen den Grenzen von Faktualität, Fiktionalität und Literarität? [Autofiction: Between the borders of factuality, fictionality, and literacy?]" In Grenzen der Literatur: Zum Begriff und Phänomen des Literarischen [Borders of Literature: On the Term and Phenomenon of the Literary], edited by Simone Winko, Fotis Jannidis, and Gerhard Lauer, 285-314. Berlin: de Gruyter. 